\title{
Risk analysis and risk management in Maesstobel
}

\author{
G. Jaeger ${ }^{1} \&$ R. Schmidt ${ }^{2}$ \\ ${ }^{I}$ Department of Civil Engineering and Natural Hazards, \\ University of Natural Resources and Applied Life Sciences, Vienna \\ ${ }^{2}$ Technical Service for Torrent and Avalanche Control, \\ Department of Bregenz, Austria
}

\begin{abstract}
The catchment area of the Maesstobel in Vorarlberg (Western Austria) has a potential rockfall volume of up to $800,000 \mathrm{~m}^{3}$. Even a smaller rockfall can already block the suggadin river. A subsequent dam failure would cause severe damages to the town of St. Gallenkirch. In order to get reasonable Hazard zone maps, hydrological and 2-D hydraulic simulations were carried out. To secure a bypassing road and to warn the inhabitants of the valley and the construction workers at site an early warning system was installed.
\end{abstract}

Keywords: debris flow, simulation, early warning, rock fall.

\section{Introduction}

The Maesstobel with a catchment area of 0,42 square kilometres, shows significant hazard potential due to rockslide in its upper reach. According to a geological study, this rockslide sped up in the course of 1999. The hazard scenario is such that $800,000 \mathrm{~m}^{3}$ of rocks and debris flows tumbling down could impound the receiving water of the Suggadin stream; there is thus the danger of dam failure and a subsequent flood wave. The hazard zone map of St. Gallenkirch, which was approved in 2002, features sizable hazard zones of high impact at the Suggadin stream's deposition fan.

The objective of the project was as follows: on the basis of new insights and recordings of the Maesstobel catchment area, the hazard potential and the consequences of a subsequent flooding for the settlement area of St. Gallenkirch were to be assessed, and on this mitigation measures were to be derived to 
minimize the risk. A geological in-depth study carried out by the Geognos Bertle company provided the basis to estimate the volume of the rock slide. Due to the new results, experts of different disciplines determined for the design event a cubature of $150.000 \mathrm{~m}^{3}$ of rocks and debris flows at the immediate confluence with the Suggadin river. This is the expected volume that initiates the impounding of the Suggadin river up to a height of 15 meters. Moreover, on the basis of a digital terrain model made up of laser scan data, a hydrological and hydraulic simulation was carried out.

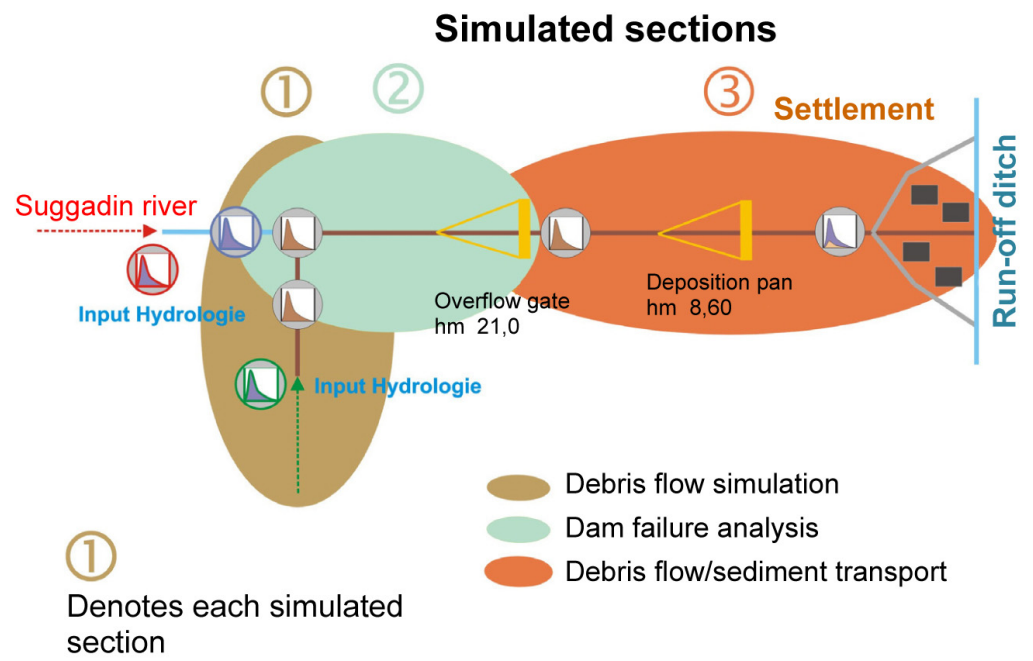

Figure 1: Diagram of simulation sections.

\section{Simulation}

The hydrological calculation was carried out for the whole catchment area of the Suggadin river by the HEC-HMS model. The hydraulic simulation as well as the dam failure scenario was arranged in three consecutive sections. Section 1 involved simulating a debris flow in the Maesstobel, including its confluence with the receiving river and the resulting maximum pileup height. This simulation was made with a hydraulic 2D software package. A rheological reading of debris sampling served as a basis for this. Section 2 dealt with the dam failure scenario, which contains possible types of dam failure with successive flooding.

These calculations were made with the help of a 1D model. Section 3, finally, contains the canyon range and the deposition fan, as well as the town area of St. Gallenkirch. In this section, the worst-case scenario of a flood wave was simulated (2D simulation model), and the areas along the deposition fan, which are potentially endangered, were determined. Building on these results and insights, a bundle of measures are now to be designed as a part of risk management. 


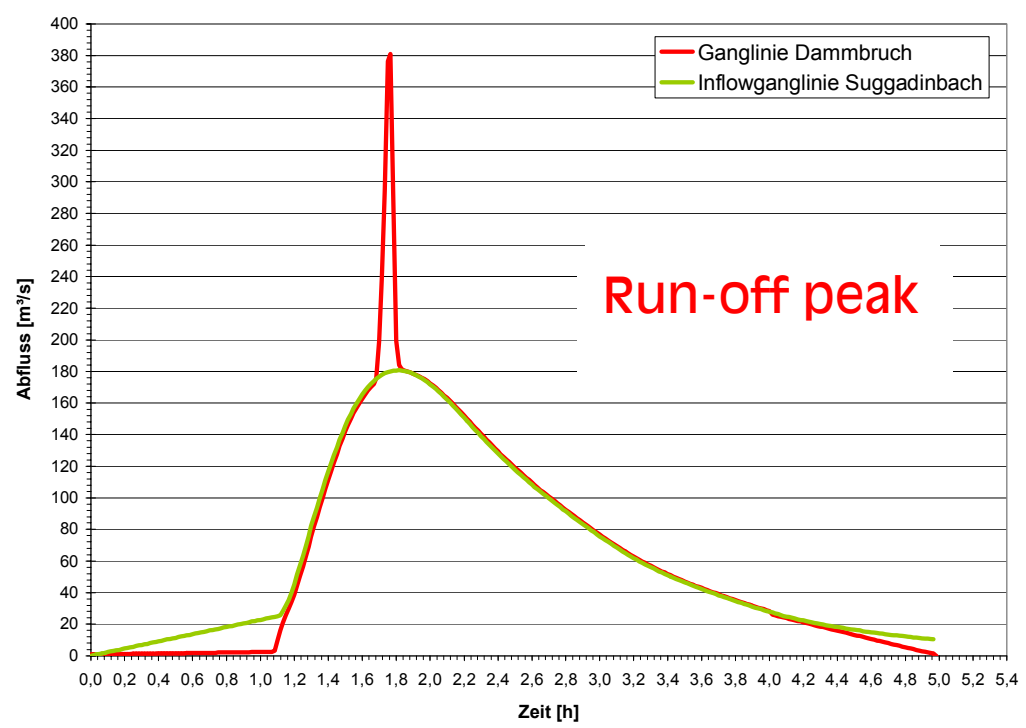

Figure 2: Runoff hydrograph of dam failure (red) and hydrograph of the suggadin river (green).

\section{Early warning system}

As part of the broad risk management approach in addition to simulation and calculation as described above, technical measures were carried out and a monitoring and early warning system was installed. In order to monitor the movement of the starting zone, 7 rope extensometers can register the changes three dimensionally.

In addition to these, 2 Inclinometers detect any changes within the loose rock area. The data is transmitted via radio and evaluated by the Geognos company. Within the falling area, two geophones register any ground vibration in order to trigger a just in time alarm that controls a traffic light which closes the nearby road.

By 2005, the whole system should be integrated within the central alarm and warning center of Vorarlberg (LWZ/RFL). This would be the first application of that kind in Austria. The LWZ/RFL collects all incoming emergency calls and distributes them to the according action and relief units immediately.

Via a secure homepage, info data can be viewed easily by any registered user, any time, any place. The alarm is set off via a secure and standardised line that is fully backuped. The LWZ/RFL is on duty, 24 hours 7 days a week. Coordination and Controling of continuative measures is easy and centralised. The LWZ/RFL provides good infrastructure (hardware/software) that can't be afforded by every community or user itself 
298 Monitoring, Simulation, Prevention and Remediation of Dense and Debris Flows

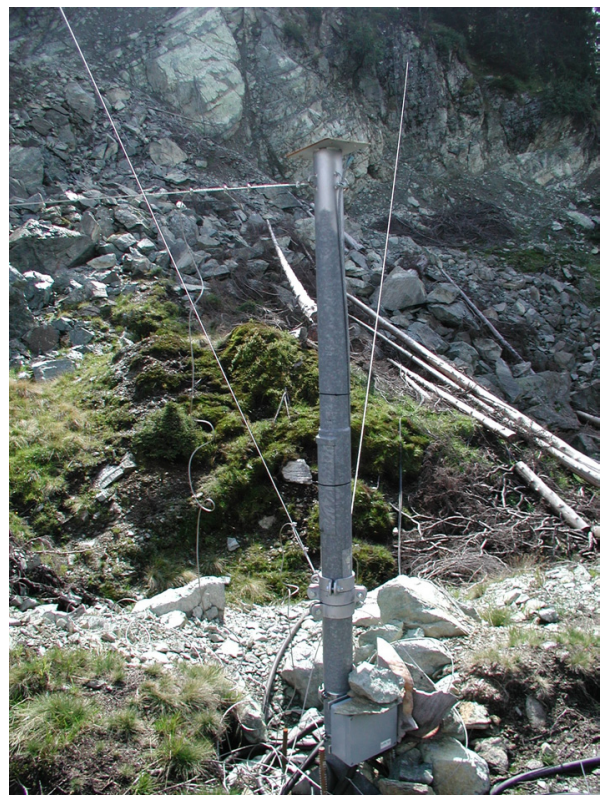

Figure 3: Rope extensometer at the starting zone.

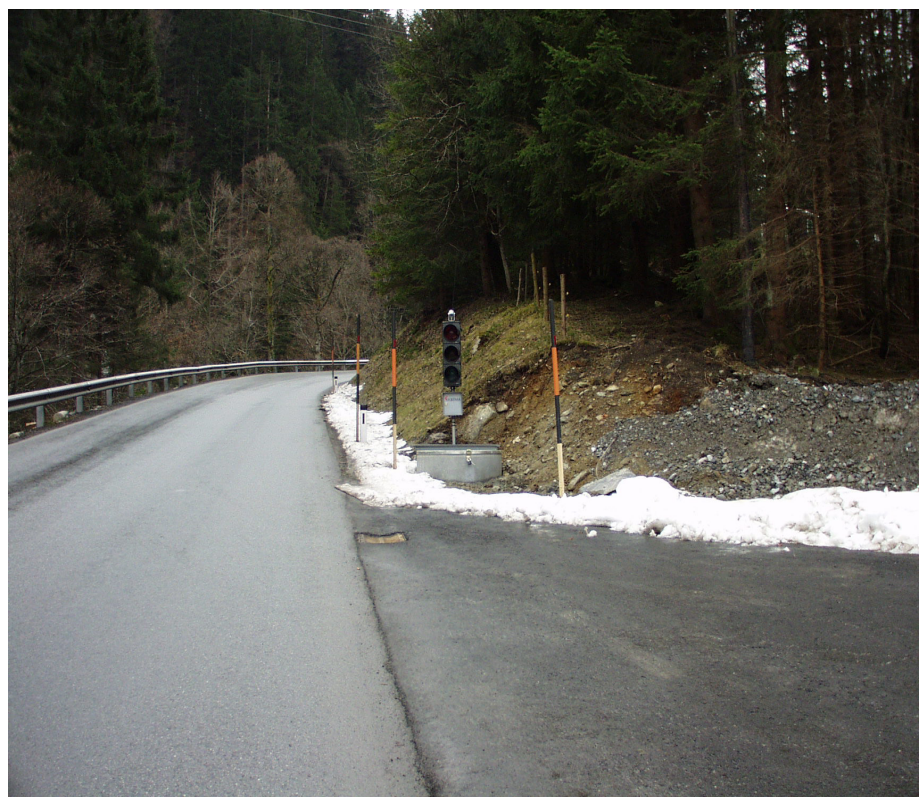

Figure 4: Road closure via traffic light. 


\section{References}

[1] Beffa, C. (2001): Diagramme zur Bestimmung der flächigen Ausbreitung von Breschenabflüssen, In: wasser, energie, luft, Heft $3 / 4$

[2] Beffa, C. (2002): Integration ein- und zweidimensionaler Modelle zur hydrodynamischen Simulation von Gewässersystemen, Int. Symposium "Moderne Methoden und Konzepte im Wasserbau"; 7.-9. Oktober 2002, ETH Zürich

[3] Geognos Bertle (2004): Felsgleitung Mäßtobel - geologischgeomorphologisch-hangtektonische Detailuntersuchung; Jahresbericht 2004

[4] Frank, J. (1951): Betrachtungen über den Ausfluss beim Bruch von Stauwänden; In: Schweizerische Bauzeitung, 69 Jg., Juli 1951, Seite401 406

[5] Hampel, R. (1960): Bruchversuch an einer Bogensperre der Wildbachverbauung; In. Österreichische Wasserwirtschaft, Heft 8/9, Jahrgang 12

[6] Forsttechnischer Dienst für Wildbach- und Lawinenverbauung Gebietsbauleitung Bludenz (WLV 2000): Suggadinbach, Verbauungsprojekt 2000, Technischer Bericht und diverse Unterlagen

[7] Forsttechnischer Dienst für Wildbach- und Lawinenverbauung Gebietsbauleitung Bludenz (WLV 2002): Mäßtobel, Bauprogramm für Einzelbaumaßnahmen 2003, Technischer Bericht und diverse Unterlagen

[8] Radler, S.,(1989): Wasserwirtschaft und allgemeiner Wasserbau (I) für KT, WW u. WLV); Studienblätter zur Vorlesung, SS 1989, Kapitel 6 Hochwasserschutz

[9] Schmidt, R. (2002): Warnsysteme in Wildbacheinzugsgebieten; Wildbach- und Lawinenverbauung Vorarlberg, 6900 Bregenz, Rheinstrasse 32/4

[10] Steinwendtner, H. (2002): Einsatzmöglichkeiten von Numerischen Modellen im Zuge der Maßnahmenplanung in geschiebeführenden und murfähigen Wildbächen; unveröffentlicht. 